\title{
ROMAN LAW IN ENGLISH LITERATURE
}

Lawyers have a natural interest in studying their portraits by masters of literary form; even when the pictures are far from flattering they may still en joy the sight of what is most loved because most familiar. Then, too, law and literature are related by affinity if not consanguinity. The briefless barrister ekes out his slender means by literary contributions; the advocate is not adverse to an occasional peep at a dictionary of quotations; the retired leader writing his memoirs brushes up his Cicero as one would an ancient "topper" for wedding or funeral. Now and again a student of the law deserts the bar for the more lucrative and conspicuous career of letters, rarely, as in the case of Sir Walter Scott, managing to combine both professions, although it is to be feared that literature is not flattered by this association with a profession whose most cherished forms are dismissed as a barbarous jargon. Law also, when safely perched on its own mediaeval battlements, looks down with condescending eye on the literary artist caught in the tortuous passages that surround its feudal castle, likely at any moment to slip into the moat or break his neck in some dark procedural hole.

Since law supplies much of the framework of social institutions, it is scarcely possible to write on human character and conduct without expressly or tacitly taking into consideration those rules of law which govern the normal relations of mankind. Rules of the everyday sort, familiar to layman as well as lawyer are taken for granted, and upon obscure points careful writers consult professional friends. There is too, that type of short story by which through the exercise of sharp practice and legal evasions, virtue and vice are more or less impartially rewarded. Upon the stage ludicrous exaggerations occur and even more so on the screen-that drab foundling of the Arts. But to the drama a good-natured license is allowed in depicting the common phenomena of life; as Shaw says, "the theatre imposes unities of time and place from which nature in her boundless wastefulness is free." In dealing with bench and bar the writer of fiction stands on less slippery ground; he may know little or nothing of law, but he does know a lawyer or two who offer a 
fair mark for his pencil. The shyster, ignorant and insolent with his disreputable train of runners; the counsellor of good repute with neat brief case and primly pessimistic outlook; the overworked and overheated judge desperately afraid of a breath of fresh air; these, and other types equally familiar, offer excellent material for portraiture. But the novelist will not be permitted to forget that the interest of his readers is centered not on the vagaries of jurisprudence but the misconduct or misfortune of his puppets. Where bigamy has occurred it is not a doubtful point in the law of domestic relations that will hold the reader but whether hero and heroine were pleased or disappointed. Warren in "Ten Thousand a Year" made a gallant effort to write a novel around the action of ejectment, but it is doubtful if that unusual book can be classed as literature Baron Parke is said to have sent a special demurrer to a sick friend for his entertainment, but the result is not recorded.

Hence, in the background of romance the lawyer appears, does his little turn and vanishes, a minor figure in the scene, the hero's heavy friend or the villain's wicked confidante. Balzac's novels teem with litigation; Dickens has caricatured the courts and Thackeray has pencilled the social atmosphere of the Inns of Court; but the legal mind does not seem to have aroused the interest of the literary psychologist. Life at the bar, its etiquette, its shibboleths, its sophistries, its loyalties, its stern moral conflicts and unremitting labor, offers a more fertile field in modern fiction than theology or medicine without attracting nearly as much attention. The hero, whoever he be, is at odds with fate or frustrated by social conventions and the lawyer is merely the mouthpiece of conventions assumed to be soulless. Perhaps it is all for the best, and this is certainly not to be taken as a challenge to contemporary letters, especially now that law after a carnival of egoism sits in sociological sackcloth. A long-winded, dull, conscientious story about a long-winded, dull lawyer, conscientious or not would be less entertaining than Tidd's Practice or Austin's Jurisprudence. The pattern of the law is somewhat intricate for romance; nor would we be pictured in the Russian style, dead and dug up, or tailing off into chaos. A preference 
for the urbane spirit of the Renaissance leads to the expression of a pious hope that we may be spared a life-size portrait until the influence of that radiant age revives.

If then the literateur hesitates to intrude upon the common law, that sphere where the sage is presumed to be secure and only devils fear to tread, by how much the more should he avoid the law of a foreign jurisdiction and of another age? The presence then of Roman Law and its derivatives in English literature is, as one would expect, fragmentary and accidental, so uncommon in fact that a search for and enumeration of all the instances would be sufficiently tedious to form the subject of a doctor's dissertation. In suggesting a few examples Sir Walter Scott comes first to mind. As an advocate, judge and clerk of the Court of Session, the highest Court in Scotland, he spent much of his busy life in the atmosphere of the courts. All that need be said on that subject has been entertainingly told already. Roman law was received in Scotland as part of the common law of the realm and was a most important element in the training of the bar, but the property law of Srotland was essentially feudal and it is feudal law that predominates in his romances. There are references to the corpus juris civilis and the corpus juris canonici in Ben Jonson's "Epicoene or the Silent Woman," and a debate between Captain Otter and Cutbeard, the barber, disguised respectively as a divine and a canon lawyer, upon the subject of divorce, where there is much heavy fooling and quoting of Latin tags. It is amazing that the groundlings should have enjoyed these pseudo-erudite discussions until one remembers that Latin grammar was then the foundation of an education and observes an American audience apparently charmed by a little speech in French which it does not understand but which carries it back to happy high school days.

All would agree that the most famous lawsuit in literature is Shylock v. Antonio. Much nonsense has been written about Shakespeare's law and the Merchant of Venice has drawn the

The Law and Lawyers of Sir Walter Scott in The Lawyer in Literature by John Marshall Gest, p. 67 reprinted from Usiversity of PenssyzVANIA LAW REVIEW. 
fire of unfriendly as well as friendly critics. It would be unprofitable to repeat these criticisms as the subject has recently been wittily reviewed in a brochure by Sir George Greenwood. ${ }^{2}$ The play, it must be remembered, is a comedy; the work of a man of genius whose knowledge of law, in the words of Professor Schelling, "like his knowledge of everything else, was that of a man who saw life directly, not life reffected through books; it was accurate to an amazing degree where he had occasion to fix his gaze; careless, where carelessness affected no damage to his art, and generally far above that ordinary level of information which we demand of other men." s The plot is mainly from the Italian novel, "Il Pecorone," by Ser Giovanni, which Shakespeare must certainly have read. But the Jew of Venice and his bond appear in manuscript versions of the Gesta Romanorum, in ballads and other sources, indicating that it was an old and favorite tale of the Middle Ages." What gave zest to the story was the fact that Shylock was caught between the horns of a legal dilemma, a predicament always fascinating to the lay mind usually unconscious of the vast number of conflicts which the haphazard growth of the law calls into existence. Shylock was entitled to his pound of flesh but could not take possession without subjecting himself to prosecution, and incidentally was robbed of his money. Very true. But a modern Shylock in lawful possession of a barrel of wine is in just an awkward predicament if the house takes fire. The wine is his property, but if he moves it without a permit he may be arrested, and will get just as little sympathy from the unelightened descendants of Shakespeare's groundlings.

However, it is the procedure in the play that has caused the most criticism; the absence of a jury and other paraphernalia of a common law trial has troubled the mind of more than one serious minded practitioner venturing into literature. It would be overstraining antiquarian research to pin down this lively

\footnotetext{
-Shakspeare's Law by Sir George Greenwood (1920). See also Shakespeare von der Forum der Jurisprudenz by Josef Kohler; Shylock v. Antonio. Judgment Aftrmed by George Wharton Pepper, 40 Amer. Law Reg. 224.

Book Review by Prof. F. S. Schelling, 7o U. of PA. LAw Rev. 14t.

- Appendix to the Merchant of Venice, Variorum Edition by Horace Hopard Furness.
} 
product of the theatre to formal compliance with the methods of a particular jurisdiction; the sources, moreover, do not tell the story in the same way. It is sufficient to remember that the scene is laid in Italy, where Roman law survived in a modified form. In the ancient capital of the civilized world there existed a body of learned jurists who gave advice on points of law to litigants, to magistrates and to the julcx-a private person appointed by the practor to hear and determine a particular case. Under the empire the opinions of certain designated jurists were given the force of law (jus respondendi), which the magistrate was required to follow, so that opinions of the privileged jurists (responsa prudentum) were an important source of law; were collected and embodied in the texts. ${ }^{5}$ Under the later despotism this practice was abandoned but the tradition remained, and throughout the Middle Ages the opinions of learned counsel (consilia or responsa) carried great weight and are cited with about the same frequency as the judgments of the courts (decisiones). Hence the important role played by Portia as the substitute for the distinguished doctor, Bellario, first consulted by the Duke." But, as Sir George Greenwood points out, Shakespeare's only concern was to make a delightful comedy amid Italian scenery, "and not being a stolid dolt, he would not concern himself a two-penny button about the laws of England and the practice in the King's Bench." - The only unfortunate consequence of the dramatization of the mediaeval tale is that every young woman who studies law is tagged Portia. Indeed to the more thoughtful members of Shakespeare's audiences the foreign legal procedure would have appeared much less disturbing than to the good citizens of Frozen Dog or wherever it may be that Shakespearean controversy waxes warmest. The age of Elizabeth and James I was one of continental and especially Italian influence which affected law no less than literature. Roman law was the fashion at Court, threatening for a time the supremacy of the common law.? But it is

- Ortolan's History ol Roman Law (Eng. Ed. 1871); Moyle's Introduction to Justinian's Institutes, p. 57.

- Merchant of Venice, Variorum Edition, p. 417.

- English Law and the Renaissance, Maitland, I Select Essays in AngloAmerican Legal History 168; 5 Holdsworth's History of English Law (2 ed.) 155. 
questioning the intelligence of the audiences of that brilliant period to suppose that a foreign, or even purely imaginary, setting for a sparkling comedy would interfere with their enjoyment. It is not the theatre-goer, but the paper-reader who is usually guilty of such banalities.

From the Merchant of Venice to Shelly's famous tragedy, The Cenci, is somewhat of a leap, but is excused by the fact that the plot of this somber play is derived from the tale of horror revealed on the trial of Beatrice Cenci, her mother-in-law, and brothers at Rome in 1598 for the murder by a hired assasin of Count Francesco Cenci, the parent and husband of the defendants; a case famous in the annals of Italian criminal law. The prisoners; who were all convicted and all executed except one brother, a minor, were ably represented by Prosper Farinacius, reputed to be the greatest advocate of his day and the author of learned and voluminous works covering the entire field of law, resembling in this respect his English contemporary, Sir Edward Coke, although unlike the high-minded Chief Justice, the morals of Farinacius are reputed to have been bad. The argument on behalf of the prisoners to the Pope for executive clemency is preserved in the works of Farinacius and is an able document. It would seem that the charge of incest made against the Count was not proved although there is apparently little doubt that Beatrice was beaten and imprisoned by her father. The trial scene in the play does not touch directly on the juristic aspects of the tragedy. The poet, inspired by the supposed portrait of Beatrice by Guido Reni in the Barberini palace, deriving his facts from a manuscript giving but an imperfect account of the affair, and finding a theme that superbly illustrated his theory of life-a world of tyrants and heroes-was absorbed wholly in the supreme moral conflicts involved. ${ }^{8}$ The trial, for all that appears, might have taken place in any country where the inquisitorial procedure was in force and torture employed. The court is no more than a conventional background for the locution of the players, as is perfectly

- A study of Shelly's Drama, The Cenci, by Emest Sutherland Bates, 1908. Since this paper was written Corrado Ricci's work on Beatrice Cenci has appeared in a translation by Morris Bishop and Henry Longan. 
legitimate in a closet-drama dealing chiefly with abstract ideas. It is not Latin in spirit: Shelly was not of that clime or culture.

But, after all, the real excuse for this lucubration is Judge Gest's new translation and explanation of The Old Yellow Book, the source of Robert Browning's poem, The Ring and the Book. In 1860 the poet purchased from a dealer in secondhand oddities in the square of San Lorenzo, Florence, an old vellum bound book containing a collection of pamphlets, mostly in Latin, relating to the trial of Guido Franceschini and his hired accomplices for the killing of his wife, Pompilia, and her reputed parents, Pietro and Violante Comparini at Rome in 1698. It included briefs of argument, pamphlets and letters bearing on the case bound together, it would seem by Francesco Cencini, a Florentine lawyer who may have had some professional connection with the Franceschini family. The story, now sufficiently familiar, may be briefly summarized. Count Guido Franceschini, of a noble but impoverished Tuscan family, sought to recoup his fortunes by marrying, in 1693 . Pompilia, the supposed daughter of the Comparini who were middle class Romans. The bride, little more than a child, and her parents, accompanied the Count to his home in Arezzo. There bitter quarrels arose and the Comparini, returning to Rome, claimed that Pompilia was not their child, but of ignominious parentage and sued to recover back her dowry. This suit they lost, but appealed to the Sacred Rota. The bittemess increased and in 1697 Pompilia fled from Arezzo to her former home escorted by Guiseppe Maria Caponsacchi, a young noble, and canon of the church of the Pieve.at Arezzo (not a priest, as stated by Browning). On the way they were overtaken at Castelnuovo by Franceschini and arrested on the charge of elopement. Caponsacchi was banished, or rather relegated to Civita Vecchia for three years, and Pompilia placed in a nunnery, whence a month later she was transferred to the custody of her foster parents in Rome, and there in December, 1697, she gave birth to a son. On January 2, 1698, Frances-

- The Old Yellow Book by John .Marshall Gest, Boston 1925, Chipman Law Publishing $\mathrm{Ca}$. 
chini, accompanied by four countrymen hired to assist him, entered the house of the Comparini by stratagem, stabbed the parents to death and mortally wounded Pompilia. The assassins were arrested on the road, brought back to Rome and tried before the vice governor Marco Antonio Venturini, where the prosecution was conducted by Francesco Gambi, Procurator of the Fisc, and Giovanni Battista, Advocate of the Fisc, while the prisoners were represented by Giacinto Archangeli, as Procurator of the Poor, and Desiderio Spreti, as Advocate of the Poor. All were distinguished members of the Roman bar, the defense as well as the prosecution, it will be noted, represented, as was the Italian practice, by state officials. The case was a celebrated one, conducted on both sides with masterly skill. As is usual, now as well as then, where there is no disputing the facts the defense was that the crime had been committed hororis causa, the familiar appeal to what is known in newspaper parlance as "the unwritten law." The defense was unsuccessful and on February 18, 1698, Guido and his associates were sentenced to death. As Guido was alleged to have been admitted to some lesser clerical order, and as one of the associates was a minor, an appeal was made to the Pope for clemency, which was promptly denied, and on February 22, 1698 , in the Piazza del Populo, in the presence of a vast concourse of people, Guido was beheaded and his accomplices hanged.

Omitting reference to the maze of incidental litigation, Guido's prosecution of Pompilia at Arezzo appealed to Florence, the proceedings against Pompilia and Caponsacchi (processus fug(ce), before the governor of Rome; Pompilia's suit against Guido for a judicial separation and, finally, the contest over Pompilia's estate after her death, the above is a brief outline of the tragic events that Browning used as the material for his-most important poem, a series of dramatic monologues in which the public, the parties, their counsel, and the Pope each tell the story as they saw it. The pitiful and sordid tale of avarice, intrigue, love, hatred, jealousy, crime and retribution, buried for long years in the formal documents of the courts, was brought to life again by the magic of the poet's genius. 
"From the book, yes; thence bit by bit I dug

The ligot truth, that memorable day,

Assayed and knew my piecemeal gain was gold,-

Yes; but from something else surpassing that,

Something of mine which, mixed up with the mass,

Made it bear hammer and be firm to file."

There are two ways of approaching a masterpiece of art or literature; one by climbing the peaks, following the artist's path, hoping in the rarefied atmosphere to catch a glint of his vision; the other by keeping in the lowly valleys, working out a trail through our own prosaic experience. While the former is more. ambitious the latter method is not without its attractions and indeed might be slyly recommended by the artist himself to those temperamentally unsuited to altitudes. More than one poet glad to be appreciated by some would be bitterly chagrined if understood by all. Browning seemed to enjoy mystifying his readers. And as throughout the poem he constantly waves the old yellow book in their faces exclaiming triumphantly, in effect, "Here is the crude source of my story; see what a splendid thing I have made of it by adding my own interpretation of the tangled facts," he challenges the public to explore the dark maze, luring it to arduous investigations, in the manner of the attractive nuisances which the law forbids us to set in the path of children. Such researches have been plentiful but would have been almost sterile had not the Old Yellow Book been given to Balliol College, Oxford, in fufillment of the poet's wish. It was reproduced by the Camegie Institution in 1908 with a translation by Charles W. Hodell, and now Judge Gest offers us a new translation with explanatory notes and critical chapters on the poem and its source. It would seem then that there are now two objects of interest; Browning's poem considered as a work of art, and the Old Yellow Book itself as a source of legal history, throwing a flood of light on an obscure period.

As to the law inrolved, J1:dge Gest tells us all that can now be learned of the counsel and judges concerned in the case, the authorities upon which they relied in their arguments, the courts of the City of Rome, and the legal procedure of Italy at the time 
of the trial, including particularly the torture which was an integral part of it. To say that this work is a most distinguished piece of historical research is less than is due. It must have cost the Judge, as he admits, an immense expenditure of time and trouble, involving as it did the collection of a special library on mediaeval and post-mediaeval criminal jurisprudence. It was not time wasted as he feared. For the student, the curtain is raised for a brief moment upon a distant scene and period and counsel speak across the years to those qualified to listen upon that perennial problem of the criminal law, summarized on the title page, probably in Cencini's handwriting, "whether and when a husband may kill his adulterous wife without incurring the ordinary penalty." $10 \mathrm{We}$ are shown the structure of a Roman brief, and the civilian method of citing and using authorities; texts of the corpus juris, commentaries, treatises, quoestiones and consilia; illustrious names are cited and names forgotten. Contrary to the common belief decisions of the courts are frequently referred to and we learn that in Italy in the seventeenth century decisions were collected, and quoted in arguments and judgments as authority on the points involved.

The learned editor has cut up the briefs and rearranged the material in its logical order according to the points discussed, a method that impairs the symmetry of the arguments, but is helpful in elucidating the points argued. The first question is whether Count Guido Franceschini and his associates should be tortured. Tpon this repellant subject there is much citation of authority and we are reminded that all important works on continental criminal procedure contained discussions and descriptions of the kinds and degrees of torture, which, originating in the criminal law of Ancient Rome, did not complete its melancholy cycle until the French Revolution. There were many kinds in use; Hippolytus de Marsilüs enumerates forty methods in Italy and they were apparently no less numerous in France.12

\footnotetext{
What any woman may kill any man without incurring any penalty would seem to be the practice, if not the law in the United States.

'Esmein's History of Continental Criminal Procedure, (American ed), 157, 270 .
} 
That used in the Franceschini trial was the Vigil, in which the victim was stretched for hours in a position of unbearable discomfort. Torture was used not to punish but to obtain that complete proof which the continental criminal law required for a sentence to capital punishment. An unwillingness to rely on anything less than proof positive led to the supposed necessity of obtaining a confession from the accused. This should interest the sentimentalists who inveigh against circumstantial evidence.

The next point argued was the question of Pompilia's guilt upon which depended the defense honoris causa. This involved an analysis and discussion of the evidence with the citation of a profusion of authorities, text writers and cases. Counsel on both sides presented their view with such learning and zeal that it is difficult at this distant day to arrive at a definite conclusion upon a point as to which certainty of proof is seldom available; Judge Gest finds her guilty, with extenuating circumstances, contrary to the poet and his disciples. There are items of evidence that do look serious; but one would like to hold a brief for the spirited girl who, when brought to bay at Castelnuovo, drew sword on Guido and might have made mince-meat of him had she not been restrained by the police. Argued with equal ability was the question whether Guido by delaying his vengeance had forfeited his right to the lenient treatment usually accorded to injured husbands. Here the prosecution had much the best of it; for even granting that detection in the act was not essential, as maintained by some contemporary writers, still the homicides were attended with a number of circumstances of aggravation and in spite of most ingenious arguments, the slaughter of the Comparinis was inexcusable. After all Franceschini was not a figure to excite the sympathy of a robust age. He was a coward. If he had killed Pompilia and Caponsacchi when he overtook them at the inn of Castelnuovo, or at least made a gallant attempt to do so, he probably would in the end have gotten off easily. But he was clearly afraid to try conclusions with the stalwart young canon, and if he brought no friends with him, it indicates either that he had none, or that his intention throughout was to rely on the law. The prosecution of the elopers certainly did not increase 
his prestige; Lamparelli who defended the pair twitted Guido for bringing this kind of suit before a judge, and Guido's brother, Abbate Paolo, who conducted his case, "excited the laughter and jeers of almost all present" It was, as Spreti observed, quoting the learned Castrensis, "husbands are reputed to be baseborn and horned if they do not take vengeance with their own hands, but wait for that to be done by the judges who laugh and roar immoderately." 12

As to the poem. Judge Gest, whose working hours are spent in the "patent truth extracting process," has some caustic criticism of the poet's treatment of the story which will not be pleasing to the perfect Browningite; contending that since real men and women were introduced Browning should "within somewhat elastic limits be true to his originals. These may be embellished in the story, but not distorted, they may be viewed from different angles, but the perspective must be preserved." This debatable ground is fought over whenever novel or play assumes to deal with historic personages. Browning did not profess to write a chronicle of events, but sought the truth through his intuitions. No doubt his intuitions are generous to the eloping couple, but then he was a romantic; an Englishman in Italy, revelling in his misconceptions as is the way of his delightful kind. If he pictured Caponsacchi and Pompilia much in the manner of Edwin and Angela of Mid-Victorian Mayfair, it was because his vigorous soul was of his own day and race, as it should be. He was as confident about his intuitions as his great contemporaries, Thomas Carlyle and Brigham Young. It was an age of certitudes.

But the candid admirer of the Ring and the Book must admit that of the monologues those of the opposing counsel are the least worth while. Indeed they are so nearly unintelligible that it is doubful if anyone today except a Browning specialist could be induced to read them at all. In the Old Yellow Book the arguments of counsel are lucid, forceful and learned; from contemporary sources we know that they were distinguished men, leaders of the Roman Bar. Why, then, did Browning picture Arch-

20ld Yellow Book (Gest), p. 354, citing Castrensis, cons. 277 a. 3, and other authorities. 
angeli as a greedy, vulgar pedant and Bottini as a vain and pompous rhetorician? Why did he write all this irrelevant nonsense interspersed with scraps of Latin from the briefs? Unfriendly persons would say that Browning, knowing little about law, and caring less, found this the easiest way to deal with refractory material. But this is not like the poet, who had considerable capacity for burrowing in dark corners. Is it not probable that, following the conventions of the contemporary novel which offset pathos with humor, Browning merely used the unfortunate lawyers to furnish the inevitable comic relief? If comedy had to be introduced they were the logical victims; and clever satire at the expense of the pawky atmosphere of the courtroom is always popular. But Browning caricatured these lawyers with a heavy hand; his elephantine jocundity, his national habit of punning, his grotesque locution are all exhibited at their worst, and at the expense of verisimilitude. All this is said with due appreciation of the great beauty of other parts of the poem, its vitality, ingenuity and color. It is one of the treasures of English literature. But with the unctious moral superiority of his age he saw these Italian dignitaries of the seventeenth century as police court practitioners. Historical criticism had not then taught the student to look with compassionate eyes at the misguided efforts of humanity and its leaders then as now like fies on sticky paper, buzzing noisily but with feet firmly fastened in habits, conventions, and precedents.

Very different indeed is the picture of judge, inquisitor, assessors, and promoter that we get in Bernard Shaw's Saint Joan, where the trial is is an ecclesiastical court, under the canon law, offspring of Roman law, by the inquisitorial procedure of the mediaeval church Shavian wit and moderninity peep from behind the lines, but the scene is substantially faithful to the spirit of the age and the probable setting of that dolorous drama, making due allowance for the playwright's necessity of rendering the characters, creatures of another age, intelligible to his audience.

One would like to say more on Saint Joan's prosecutors, but the editor's blue pencil already threatens this disquisition that has no bearing on practice. Judges and lawyers are very evidently 
not heroes of romance. Outdistanced by soldiers, sailors, tramps, cowboys and locomotive engineers, is it because a court sits? Blackstone, following Coke, defines a court as "a place wherein justice is judicially administered." Only dynamite or an earthquake can move a place. Motion, the mode of heroes, is not impossible for the jurist; he could challenge the demon busybody, he could renovate his office, but the dust might choke him or a bolshevist creep in and steal his typewriter-better sit tight like the cautious soul who feared change so much that he never changed his clothes. Passivity is not ignoble; in the East holy fakirs remain rigid for long periods; we may ever picture our lawyer sitting cross-legged like a smiling Buddha on the piled up volumes of the Corpus Juris of the American Law Institute. But such a view is too exalted; rather he is seen buried to his shell-rimmed spectacles in sheaves of stupid legislation. And there we will leave him. Other things may be insecure, but we will know where to find him when Gabriel blows his trump.

University of Penrsyluaria,

William H. Lloyd.

Philadelphia, $\mathbf{P a}$. 